\title{
A Priori Model of Constitutionality Review in Georgia: Systemic Aspects and Potential Shortcomings
}

\author{
Zaza Tavadze, PhD Candidate \\ Grigol Robakidze University, Georgia
}

Doi:10.19044/esj.2018.v14n32p18 URL:http://dx.doi.org/10.19044/esj.2018.v14n32p18

\begin{abstract}
The genesis of a priori review of legislation traces back to France, which was devised with a clear objective to ensure institutional balance and separation of powers between government branches. This model has spread all across Europe, including Georgia. The present paper, by applying analytical research methodology, aims to dwell on some of the institutional characteristics of constitutional system in Georgia and underscore potential difficulties of a priori review model that could be associated with its functioning in practice.
\end{abstract}

Keywords: A priori review, Georgia, constitutional courts, international agreements, interpretation, constitutionality.

\section{Introduction}

The concept of constitutional review generally implies putting constraints upon political powers of $s$ state. While this idea of judicial intervention in the process of political decision-making is a common characteristic of constitutional review bodies worldwide, different systems are differentiated. In respect of their temporal functioning, a priori and a posteriori review models ${ }^{1}$ are identified. The former entails the idea of judicial control before an impugned legal act is promulgated to take effect, thereby eliminating potentially unconstitutional provisions from national legislation.

The present paper aims to focus on a priori constitutionality review model in Georgia in order to investigate its systemic attributes as well as to trace potential difficulties of its operation both from institutional and practical perspective. The paper will resort to qualitative research methodology to provide analytical assessment of respective regulatory provisions and

\footnotetext{
${ }^{1}$ The two systems are sometimes referred differently in literature, as a priori and a posteriori review, also ex ante and ex post review, or as preventive and repressive review. For the purposes of the present paper, the concepts of a priori and a posteriori review will be applied as a main point of reference.
} 
constitutional jurisprudence in Georgia. For this reason, the paper will briefly present the origins of a priori review model in France to refer to systemic features that are common to a priori check of constitutionality. Subsequently, the paper will focus on judicial control of international agreements to provide the most widespread feature of a priori review, after which the Georgian system will be analysed in order to identify potential deficiencies of a priori constitutionality review.

\section{A Priori Constitutional Review: Theoretical Rationales and Institutional Features}

Despite a priori review of legislation is not commonly accepted form of constitutional justice, it has existed for a long time. Notably, it does not belong to traditional models of judicial review - American diffuse model does not recognise any form of abstract review, whereas Kelsenian centralised system implies the creation of a tribunal, distanced from legislature and able to function independently of the political process and act as a neutral arbiter between government branches (Comella, 2004: 161-163). A priori control of legislation is inherently the form of abstract constitutional review and serves the purpose of ensuring institutional balance between the executive and legislature, yet seems difficult in this case to remain substantially detached from the political process (Study on individual access to constitutional justice, 2010: 14).

A priori constitutional review was originally conceived in France, where it has existed as a sole form of judicial review for almost five decades. In order to understand the essence of a priori review, it is important to analyse political and social aspects of French history. In particular, because of past experience, parliamentary sovereignty in France was understood as a direct expression of people's power, thereby, any form of judicial control over the acts of parliament was perceived as irreconcilable with the principle of parliamentary democracy. Historical background and philosophical rationales behind the French constitutional system helps to explain mistrust of the judiciary, which was further amplified with respect to constitutional review as it was viewed a threat against the separation of powers (Aucoin, 1992: 448449). The decision by constitutional draftsmen in 1958 to establish the Constitutional Council ${ }^{2}$ with limited powers of judicial review was thereby a logical move. The Council was entitled to review constitutionality of parliamentary laws within limited timeframe before their promulgation. Notably, under the French system, a priori constitutional review may be instigated by the following political actors: the President, Prime Minister, Speakers of both houses of Parliament, and subsequent to 1974 amendments,

${ }^{2}$ Original in French: 'Conseil Constitutionnel'. 
at least 60 deputies of both parliamentary chambers. The latter change has provided a valuable mechanism for minority MPs in parliament and respectively increased the caseload of the Council (Neuman, 2012: 261). It also follows that the introduction of this mechanism helped to reinforce the mission of a priori review model to ensure the institutional balance between the executive and legislature (Goldoni, 2012: 211-213). Notably, as a result of the 2008 constitutional reform, France adopted traditional a posteriori review model as well, combined with individual complaint mechanism.

Since France is a birthplace for a priori constitutionality control model, it is proper to delve into the French system to grasp its institutional features. There is an opinion in literature, which is based on empirical study of constitutional jurisprudence that the Constitutional Council in France seems to be closer to the political process of lawmaking than to the judiciary (Sadurski, 1999: 103-104). Even more so, it has been characterised as a 'third chamber' of the legislature (Stone, 1992: 209-210). Namely, the Council is empowered to declare unconstitutional parliamentary acts in abstracto without traditional adversarial proceedings. It has been suggested that the Council mainly considers political issues and offers the Parliament its own method to achieve their political objective. Thus, the Council is said to adopt positive decisions, which are instigated by referrals from political actors, which seek to interpret somewhat ambiguous constitutional provisions (Stone, 1999: 241). The Council is therefore identified as a political institution, rather than an independent tribunal administering justice. This view is further reinforced by the appointment procedure of members of the Council, whereby the President of the republic, as well as the speakers of both houses of Parliament, to unilaterally choose members of the Council for 9 years. Similar to other jurisdictions, it is considered problematic in France that legislation does not provide for qualification criteria for candidates, not for a public hearing procedure (Brouard and Honnige, 2017: 537).

Apart from being intertwined with the political process, there are a number of advantages for a priori review model. Namely, stability and clarity of the legal system are argued to be ensured when a normative act been subject to preliminary constitutionality check because the likelihood of its future invalidation is relatively low (van der Schyff, 2010: 107-108). Certainly, a law can still be subject to a posteriori review and declared unconstitutional if its meaning has changed over time, although the chance of its unconstitutionality is not high (Brouard and Honnige, 2017: 540). Further, it is said that a priori check of draft legislation by an independent tribunal is likely to facilitate transparency of lawmaking process because it would openly provide outside expert assessment (Sadurski, 1999: 105).

As regards its negative features, its major criticisms concern the key question of constitutional legal doctrine. Namely, a priori check of legislative 
acts does not ensure that a law in question will not be subject to future constitutional scrutiny because of a different meaning it may have acquired (Comella, 2004: 472). Moreover, the Constitutional Court is likely to be less inclined to declare unconstitutional those legal norms it has positively assessed before. In order to preserve its authority, the court may be forced to exercise greater caution when conducting a posteriori review of formerly checked legislation.

It is noteworthy that the preliminary check of international treaties before their ratification is the most common form of a priori review model and exists in many constitutional systems (Safta, 2015: 2-3). The main problem identified in this context is the efficiency of the system. Namely, prevention of conflict between a given international treaty and constitution becomes dependent on the ability of the constitutional court to foresee the future (Neuman, 2015: 278). It would be problematic if the meaning of either international provisions or constitutional norms were to change. In contrast with reviewing national legislation, the constitutional court can do less to influence the future interpretation of an international treaty. It is less doubtful that if international treaty provision(s) is declared unconstitutional a posteriori, it will put the state in a difficult legal quandary. Under the 1969 Vienna Convention, the general principle of international law is provided, which states that a state cannot invoke their domestic legislation in order to justify nonobservation of international obligations. Therefore, when exercising the preliminary check of international treaties, the constitutional court ought to be careful and consider every potential implication.

Overall, it could be said that a priori review is a model of constitutionality control that allows political actors to refer disputes to a court in the course of lawmaking and, subsequently, accept its conclusion (van der Schyff, 2010: 108). It is thereby an instrument in the hands of political institutions to prevent unconstitutional legislating.

\section{A Priori Constitutional Review in Georgia: Analysis of Legislation and Jurisprudence}

Georgia's experience of constitutional jurisprudence is modest in spite of its rich historical and legal tradition. It has been almost 23 years since the current Georgian Constitution was adopted, the time which is barely enough for the reinforcement of inherent constitutional values. It is noteworthy, however, that the constitutional case-law has seen significant development, which plays a substantial role in the process of consolidation of a democratic state, conceived with the principles of rule of law.

Similar to many European countries, Georgia adopts the centralised model of constitutional review, exercised by the Constitutional Court (Article 83.1, Constitution). It conducts the abstract review of legislation and is also 
entitled to consider the constitutionality of normative acts in individual cases with respect to constitutional rights. As regards the a priori review, the Court is empowered, on the basis of respective referral, to decide on the constitutionality of international agreements subject to the ratification procedure (Article 38.2, Organic Law).

\section{A Priori Review of International Agreements: Potential} Challenges for its Proper Functioning

Georgian legislation entitles the Court to pass on constitutionality of international treaties both a priori and a posteriori (Article 38, Organic Law). The law is specific to stipulate that a constitutional submission to the Court has to be made before the moment of ratification of a given international agreement or a part thereof. The need to ratify a treaty by a legislative body may be prescribed therein, yet there are certain categories of international agreements that must obtain parliamentary consent in order to become effective for Georgia. The Constitution requires ratification of treaties, whereby the subject matter is of military nature, or an admission of Georgia in international organisation is envisaged, or concerns territorial integrity of the state or modification of the state border, or foresees borrowing or lending of resources by the state, or requires changes into domestic legislation to implement international obligations (Article 65.2, Constitution).

Notably, the procedure of a priori review of international treaties is not adversarial in nature, because the respondent does not exist in the proceedings and the Court ought to elaborate on the presented arguments on its own. The case may be referred to the Court only by a specialised subject, namely, at least 1/5 of MPs are empowered to make a constitutional submission requesting constitutionality check of an international treaty or part thereof subject to ratification. It follows that if the Court finds the contested treaty provisions unconstitutional, the Parliament is legally barred from proceeding with its ratification.

The Court has not so far been able to decide on the constitutionality of an international agreement before its formal approval by Parliament. Yet, under the Georgian legislation, similar to the most European countries, abstract a priori review of legislation is adopted, which only empowers a group of MPs to question the ratification procedure of an international treaty before the independent specialised tribunal. Other systems alike, as indicated above, the Constitutional Court of Georgia may also encounter practical challenges when exercising a priori review of international treaties.

Generally, it is hardly possible to imagine that exhaustive interpretation of legal norms, determining the scope of their future operation is practically feasible in any given jurisdiction. In the Georgian context, the Court is called to comprehensively analyse the contested international agreement and assess 
its compatibility with national constitutional standards. It is positive, however, that the Court is not strictly limited time-wise to decide on such disputes, as legislation does not provide for any limitation. At the same time, the Parliament is constitutionally precluded to go on with ratification before the constitutional dispute is decided. This gives the Court possibility to conduct a deep and comprehensive examination of the treaty provisions in question.

Moreover, the Constitutional Court may potentially find itself in two different situations while adjudging on international treaties. Namely, depending on a subject matter, the Court may be requested to evaluate the constitutionality of an international agreement that has been in force for a long time and its provisions evolved to acquire different meaning beyond its textual substance. In such case, the Court has to choose which interpretative method(s) have to be employed in the present case.

The Constitutional Court of Georgia has well-settled practice of statutory interpretation, which implies not only consideration of the textual substance of a legal provision, but also taking into account the meaning (interpretation) that it has been given in practice (by administrative authorities or ordinary courts). It seems logical to assume that by reading an international treaty in its original meaning is likely to be implausible for the purposes of constitutional justice because it could cause the Court to make an incorrect evaluation and render a priori review ineffective. In another scenario, the evolutive interpretation of a treaty may become problematic with respect to the principle of legal certainty. In particular, it is likely to be very difficult for the Constitutional Court to determine actual substance (meaning) of international norms when they have been subject to dynamic and continuous interpretation by respective international bodies. Interpretation of international legal norms by a national tribunal is, in all likelihood, to be always challenged. Certainly, the Constitutional Court, depending on its institutional mandate, is not essentially required to possess highly expert knowledge of international law so that to convincingly decide on the interpretation of international legal provisions. Accordingly, the question, of which interpretative technique is to be pursued by the Court in these cases, is difficult to answer, that makes the constitutional procedure ever more complicated in this regard.

In the second instance, the Court may be called to consider the constitutionality of an international treaty that either has not formally entered into force, or has been in force for so short period of time that there is no practice about the contested provisions. There are seems to be two logical interpretative methods that need to be applied in such a case by the Court cumulatively: a textual reading of the provisions in question combined with analysis of travaux préparatoires, which could help the Court understand the original intent of draftsmen. Yet, it could hardly lighten its load, because, as indicated above, the future transformation of legal norms, the evolution of their 
scope is so difficult to foresee that it is not going to be resolved by any interpretative technique or combination thereof. Correspondingly, it is another reason why the Court ought to exercise caution in the course of a priori review of international treaties.

As it was pointed out in this paper, a priori review of legislation is inherently intertwined with the political process of lawmaking, which could precipitate influence on the constitutional adjudication by different actors. It is thereby very important for the constitutional court, in order to maintain institutional independence and preserve its authority, to substantially distance itself from the political process and concentrate on deliberating legal arguments in the framework of the basic law.

2. A Priori Review beyond International Treaties

Georgian laws on constitutional proceedings do not explicitly establish a priori review of domestic legislation. It is however interesting, whether the existing laws provide sufficient basis as to implicitly empower the Court to exercise a priori control of parliamentary acts.

To answer this question, it is proper to recall those major institutional features that characterise a priori constitutional review, which implies constitutionality check of parliamentary laws before they are officially promulgated and in force. Under Georgian legislation, the Constitutional Court, on the basis of an individual complaint, reviews constitutionality of normative acts, which has been defined by the Court to in its material sense and involves range of parameters to determine normative character of a given legal provision (N1/494 Decision, 28.12.2010; 'Citizen of Georgia Vladimer Vakhania vs. Parliament', II-10). Namely, a legal act has to be generally applicable, obligatory to uphold and characterised by some degree of abstraction and repetition.

It is essential to analyse these parameters in order to determine whether draft parliamentary laws, which have undergone all stages of procedural lawmaking yet not been promulgated, might be classified as normative acts. The said characteristics should be interpreted in light of the Rule of Law principle, which, inter alia, implies that a legal act has to be legitimate. It is for this reason that the Constitution sets out a procedure of lawmaking that is based on the principle of separation of powers and requires the approval of draft legislative acts by a neutral arbiter outside of Parliament. Namely, the President is empowered to sign and promulgate parliamentary laws. Clearly, the Parliament enjoys ultimate superiority to adopt and promulgate laws without presidential consent, although it is a deviation from ordinary legislative procedure. Nonetheless, it seems fair to say that in both cases when a draft parliamentary law is not formally promulgated, it ought not to be considered as a normative act, since it would lack legitimacy and thereby, fail 
to be subject to a priori constitutionality check. In short, the existing regulatory model in Georgia does not provide for a possibility to challenge draft laws adopted by the Parliament, via individual complaint procedure, before the Constitutional Court.

However, another potential scenario has to be noted, whereby a parliamentary legal act is promulgated, yet it provides for a late date of entry into force. It would seem hard to imagine such a case outside of the scope of constitutionality review, but an important question is if this check would qualify as a priori review. It needs to be recalled that some of major characteristics of this review model are its abstract nature and a specialised group of political actors that are entitled to refer a case before a court. It is a way for a parliament to 'rectify' their mistake without instigating a new legislative procedure. The given instance is likely to fall outside of the scope of traditional understanding of a priori constitutional review.

Moreover, the mentioned scenario may potentially occur in the course of abstract constitutional review. In particular, it is interesting to know whether the President of Georgia may refer a draft legal act, which has been submitted by the Parliament for promulgation, to the Constitutional Court for a priori review. This issue was raised in Moldova when the Constitutional Court opted for systemic interpretation of the Constitution and laws to conclude that since the Court enjoys general powers to consider constitutionality of laws on the basis of an individual complaint, it is not barred by the Constitution from reviewing constitutionality of laws not duly promulgated (Decision CCM no. 9 of 14 February 2014 for interpretation of Article 135 (1) a) of the Constitution of the Republic of Moldova). Notably, the Moldavian Constitution and legislation refer such parliamentary act as a 'law', which provided basis for the Court to display extraordinary judicial activism and open the door for constitutionality review of draft parliamentary acts.

By contrast, textual substance of Georgian legislation, as well as it structure, does not offer much prospect for constitutional jurisprudence to develop towards the same direction. This paper reviewed the theoretical framework of a priori review and pointed out to the risk of distortion of the separation of powers. Namely, if we accept the idea that institutionally independent judicial body participating in the political process of lawmaking, it is likely to result in the politicisation of constitutional justice, which could undermine the principle of judicial independence and thereby, damage the legitimacy of constitutional decision-making. Correspondingly, it seems reasonable to ask when considering the expansion of constitutionality review over draft legal acts, whether it is practically feasible for the Constitutional Court, which might find itself close to parliamentary politics, to maintain institutional autonomy and effectively discharge its constitutional mandate - 
to uphold institutional balance and separation of powers between the government branches, and protect fundamental rights and freedoms.

\section{Conclusion}

The objective of this paper was to explore institutional and practical aspects of a priori constitutionality review in Georgia. It started with a brief history of a priori review model in France in an effort to present main ideological rationales that formed the basis for its evolution. It is argued that the French model was conceived in order to protect the separation of powers between state organs, which is, inter alia, ensured by entitling a limited number of political actors with the power to initiate constitutional proceedings. The foregoing feature and its role in the law-making procedure makes constitutional body of a priori review closely interrelated to the political process.

As a particular example of a priori review, the preliminary control of international agreements is conducted before its ratification by the parliament. The proceedings before the constitutional court are somewhat distinct in this respect due to varying effects of its outcome on domestic an international law. It would appear that a priori review of international agreements, meaning that it has not become applicable, could be more favourable for the state, since $a$ posteriori check might well put its international obligations at stake.

The subsequent part of this paper dealt particularly with the Georgian model of a priori review and reflected on its important institutional features in the light of traditional French system. The paper identified some of the shortcomings of a priori check in Georgia and provided their analysis vis-àvis fundamental constitutional principles.

Due to its inherent connection with the political process, the major challenge before the Constitutional Court appears how to maintain its institutional autonomy while discharging a priori review of legislation and ensure fully independent and neutral adjudication in line with the original Kelsenian understanding. It is worth noting that divergence between the French a priori review model and the traditional Austrian system is evident in the Georgian context, where the centralised body of constitutional supervision is established. In the same vein, it is also empowered with a priori check of legislation, which could cause politicisation of the Constitutional Court and thus undermine the essence of its original Kelsenian conception. Nonetheless, it is fair to note that it is for evolving jurisprudence to cope with existing practical difficulties and to ensure a priori review is conducted effectively and consistently. 


\section{References:}

Legal Acts

1. Constitution of Georgia. 1995. 31-33. Tbilisi, N786.

2. Law of Georgia on Constitutional Proceedings. 1996. 5-6. Tbilisi, N159.

3. Organic Law of Georgia on Constitutional Court of Georgia. 1996. 001. Tbilisi, N95.

4. United Nations, Vienna Convention on the Law of Treaties, 23 May 1969, United Nations, Treaty Series, vol. 1155, p. 331, available at: http://www.refworld.org/docid/3ae6b3a10.html [accessed 10 January 2018]

5. Books

6. Comella V. F. (2004), The European model of constitutional review of legislation: toward decentralization? New York: Oxford University Press.

7. de Visser M. (2014), Constitutional Review in Europe: A Comparative Analysis. Oxford: Hart Publishing.

8. Stone A. (1992), The Birth of Judicial Politics in France. New York: Oxford University Press.

9. van der Schyff. G. (2010), Judicial Review of Legislation: A Comparative Study of the United Kingdom, the Netherlands and South Africa. The Netherlands: Springer.

Articles

10. Aucoin L. (1992), Judicial Review in France: Access of the Individual Under French and European Community Law in the Aftermath of France's Rejection of Bicentennial Reform. International \& Comparative Law Review, Vol. 15, No. 2. 443-469.

11. Brouard S. and Honnige C. (2017), Constitutional courts as veto players: Lessons from the United States, France and Germany. European Journal of Political Research, Vol. 56. 529-552.

12. Friedent L.A. (1998), New Citizenship, "Media \& Society", Vol. 18, No. 2.

13. Goldoni M. 2012. At the Origins of Constitutional Review: Sieyès' Constitutional Jury and the Taming of Constituent Power. Oxford Journal of Legal Studies, Vol. 32, No. 2. 211-234.

14. Hunter-Henin M. (2011), Constitutional developments and human rights in France: One step forward, two steps back. International and Comparative Law Quarterly, Vol. 60. 167-188.

15. Nastic M. (2015), Constitutional Review of International Agreements from Comparative Perspective. Law and Politics, Vol. 13, No. 1. 59-72. 
16. Neuman G. (2012), The Brakes that Failed: Constitutional Restriction of International Agreements in France. Cornell International Law Journal, Vol. 45, No. 2. 257-365.

17. Sadurski W. 1999. Judicial review, separation of powers and democracy: the problem of activist constitutional tribunals in postcomunist Central Europe. Studi Politici. Numero monografico dedicato all'Europa Centro Orientale, Vol. 3. 93-120.

18. Shapiro M. 1989. Judicial Review in France. Journal of Law \& Politics, Vol. 6. 531-548.

International Documents

19. CDL-AD(2010)039rev-e. Study on individual access to constitutional justice - Adopted by the Venice Commission at its 85th Plenary Session (Venice, 17-18 December 2010).

Electronic Publications

20. Philippe X. 2016. Jurisdictional control and the Constitutional court in the Tunisian Constitution. Constitution of Tunisia: Part 3. http://www.arabstates.undp.org/content/rbas/en/home/library/Dem _Gov/the-constitution-of-tunisie-/the-content-of-theconstitution.html (19.12.2017).

21. Safta M. 2015. Constitutional review of international treaties. Titu Maiorescu.

https://www.academia.edu/32885193/Constitutional_review_of_in ternational_treaties (19.12.2017). 